\title{
Niat Menggunakan E-commerce: Suatu Pendekatan \\ Technology Acceptance Models \\ (Studi Pada Usaha Mikro, Kecil dan Menengah Di Kota Bengkulu)
}

\section{THE INTENTIONS USING E-COMMERCE: THE TECHNOLOGY ACCEPTANCE MODELS SOME APPROACHING. (Study on Micro small and Medium Enterprises in Bengkulu City)}

\author{
Fatrisya Marsyadini ${ }^{1}$ ), Nila Aprila, SE., M.Si., Ak,CA ${ }^{2}$ \\ Universitas Bengkulu, Jl. WR. Supratman,Kandang Limun, Muara Bangkahulu, Bengkulu \\ fatrisyamars@gmail.com ${ }^{l}$ ),nilaaprila@unib.ac.id ${ }^{2}$ )
}

\begin{abstract}
ABSTARACT
This study was aimed to determine the effect of (1) the perceived ease of use, (2) the perceived usefulness, (3) the attitude towards using, and (4) the intention to use in using the E-commerce on the SMEs in Bengkulu city. The characteristics of the SMEs that were used in this study are the SMEs that are listed on the Department of Cooperatives and SMEs in Bengkulu city in the marketing field, that have not using the E-commerce for business activities yet, but already familiar with E-commerce in private, and already completed the training related to electronic commerce, SMEs recording and accounting. The populations in this study were the SMEs registered in the Department of Cooperatives and SMEs in Bengkulu City in the marketing field. Based on the Purposive Sampling Method, the samples obtained were 87 SMEs. The data is analyzed using SmartPLS 2.0 M3. The analysis shows that the perceived ease of use positively affects perceived usefulness, ease of use perceived positively effects the attitudes towards using, the perceived usefulness positively effects the attitudes towards using, the perceived usefulness positively effects the intention to use, and attitudes towards using positively influences the intention to use in using e-commerce in SMEs in Bengkulu city.
\end{abstract}

Key words: perceived ease of use, perceived usefulness, attitude towards using, intention to use

\section{ABSTRAK}

Penelitian ini bertujuan untuk mengetahui pengaruh (1) persepsi kemudahan penggunaan, (2) manfaat yang dirasakan, (3) sikap terhadap penggunaan, dan (4) niat untuk menggunakan dalam menggunakan Ecommerce pada UKM di kota Bengkulu. Karakteristik UKM yang digunakan dalam penelitian ini adalah UKM yang terdaftar di Departemen Koperasi dan UKM di kota Bengkulu dalam bidang pemasaran, yang belum menggunakan E-commerce untuk kegiatan bisnis, tetapi sudah akrab dengan E -commerce secara pribadi, dan sudah menyelesaikan pelatihan terkait dengan perdagangan elektronik, pencatatan dan akuntansi UKM.

Populasi dalam penelitian ini adalah UKM yang terdaftar di Departemen Koperasi dan UKM di Kota Bengkulu dalam bidang pemasaran. Berdasarkan Metode Purposive Sampling, sampel yang diperoleh adalah 87 UKM. Data dianalisis menggunakan SmartPLS 2.0 M3. Analisis menunjukkan bahwa persepsi kemudahan penggunaan secara positif mempengaruhi persepsi kegunaan, kemudahan penggunaan dirasakan secara positifmempengaruhi sikap terhadap penggunaan, persepsi kegunaan berpengaruh positif terhadap sikap terhadap penggunaan, persepsi kegunaan berpengaruh positif terhadap niat untuk menggunakan, dan sikap terhadap penggunaan positif. mempengaruhi niat untuk menggunakan e-commerce di UKM di kota Bengkulu.

Kata kunci: persepsi kemudahan penggunaan, persepsi manfaat, sikap terhadap penggunaan, niat untuk menggunakan

\section{PENDAHULUAN}

Globalisasi adalah suatu keadaan yang mendunia dimana hubungan sosial dan saling ketergantungan antar negara dan antar manusia semakin besar, batas-batas kedaulatan suatu negara dan bangsa menjadi kabur serta keputusan atau kegiatan dibelahan dunia yang satu dapat mempengaruhi keputusan belahan dunia yang lain termasuk negara di kawasan Asia. Dalam 
dunia perdagangan globalisasi membuat persaingan bisnis menjadi semakin kuat. Dan jika bisnis yang dikelola ingin tetap bertahan maka diperlukan usaha yang lebih dalam mengembangkan produk diantaranya bagian pemasaran, produksi, sistem akuntansi penjualan, sistem penerimaan kas, teknik pencatatan dan pembukuan transaksi akuntansi keuangan usaha.

Sistem Informasi Akuntansi (SIA) juga menangkap dan mencatat dampak keuangan dari transaksi yang terjadi di perusahaan serta mendistribusikan informasi transaksi ke personel operasi untuk mengkoordinasikan berbagai tugas utamanya (Hall, 2007). Perdagangan elektronik (e-commerce) merupakan salah satu kegiatan yang dilakukan sebuah bisnis, kegiatan dalam perdagangan elektronik ini akan berdampak pada sistem informasi akuntansi dalam suatu usaha atau bisnis, karena transaksi keuangan yang merupakan tahap awal dari suatu siklus akuntansi yang terjadi seperti transaksi penjualan dan transaksi pembelian dilakukan melalui sistem elektronik, dan hal ini akan berdampak pada pemrosesan transaksi tersebut hingga menjadi laporan keuangan yang akan dikomunikasikan kepada pemakai.

Perkembangan teknologi ini mulai mempengaruhi sistem perkembangan perdagangan, bahkan teknologi informasi saat ini berperan sebagai sarana transaksi bisnis online melalui media berupa internet (Utami, 2012). Ternyata hal ini membawa dampak yang memaksa beberapa bisnis tradisional harus memikirkan ulang cara bisnis mereka untuk menerapkan teknologi informasi dalam aktivitas bisnisnya untuk menghadapi persaingan global (Santosa, 2002).

Penelitian ini mereplikasi penelitian Lesmono (2015). Perbedaan penelitian ini dengan penelitian Lesmono (2015) adalah pada penelitian Lesmono (2015) objek penelitiannya adalah pelaku UKM di kota Jakarta Barat, sedangkan dalam penelitian ini objek penelitiannya adalah UMKM di Kota Bengkulu. Oleh sebab itu untuk dapat mempertahankan usaha dan meningkatkan kinerja usahanya serta teknik penjualan dan penerimaan kas, UMKM perlu mencoba berinovasi. Yang biasanya transaksi penjualan dan pembelian dilakukan secara langsung menjadi memanfaatkan teknologi informasi berbentuk internet untuk menggunakan e-commerce.

Berdasarkan latar belakang di atas, maka permasalahan pokok dalam penelitian ini adalah 1) Apakah kemudahan penggunaan yang dirasakan (perceived ease of use) berpengaruh positif terhadap manfaat yang dirasakan (perceived usefulness) dalam menggunakan e-commerce pada UMKM di Kota Bengkulu?, 2) Apakah manfaat yang dirasakan (perceived usefulness) berpengaruh positif terhadap sikap terhadap penggunaan (attitude towards using) dalam menggunakan e-commerce pada UMKM di Kota Bengkulu?, 3) Apakah kemudahan penggunaan yang dirasakan (perceived ease of use) berpengaruh positif terhadap sikap terhadap penggunaan (attitude towards using) dalam menggunakan e-commerce pada UMKM di Kota Bengkulu?,4) Apakah sikap terhadap penggunaan (attitude towards using) berpengaruh positif terhadap niat untuk menggunakan (intention to use) dalam menggunakan e-commerce pada UMKM di Kota Bengkulu? Dan 5) Apakah manfaat yang dirasakan (perceived usefulness) berpengaruh positif terhadap niat untuk menggunakan (intention to use) dalam menggunakan e-commerce pada UMKM di Kota Bengkulu ?

Sesuai dengan permasalahan yang dikemukakan pada rumusan masalah, maka tujuan penelitian ini adalah 1) Membuktikan bahwa kemudahan penggunaan yang dirasakan (perceived ease of use) berpengaruh positif terhadap manfaat yang dirasakan (perceived usefulness) dalam menggunakan e-commerce pada UMKM di Kota Bengkulu, 2) Membuktikan bahwa manfaat yang dirasakan (perceived usefulness) berpengaruh positif terhadap sikap terhadap penggunaan (attitude towards using) dalam menggunakan e-commerce pada UMKM di Kota Bengkulu, 3) Membuktikan bahwa kemudahan penggunaan yang dirasakan (perceived ease of use) berpengaruh positif terhadap sikap terhadap penggunaan (attitude towards using) dalam menggunakan e-commerce pada UMKM di Kota Bengkulu, 4) Membuktikan bahwa sikap terhadap penggunaan (attitude towards using) berpengaruh positif terhadap niat untuk 
menggunakan (intention to use) dalam menggunakan e-commerce pada UMKM di Kota Bengkulu dan 5) Membuktikan bahwa manfaat yang dirasakan (perceived usefulness) berpengaruh positif terhadap terhadap niat untuk menggunakan (intention to use) dalam menggunakan e-commerce pada UMKM di Kota Bengkulu.

\section{KERANGKA TEORITIS DAN HIPOTESIS}

\section{Technology Acceptance Model (TAM)}

Technology Acceptance Models (TAM) merupakan adaptasi dari Theory of Reasoned Action (TRA) yang diperkenalkan oleh Davis pada tahun 1986. TRA pertama kali diperkenalkan oleh Ajzen dan Fishbein dalam Jogiyanto (2007). Teori ini menghubungkan antara keyakinan (belief), sikap (attitude), kehendak (intention) dan perilaku (behavior).

Technology Acceptance Models (TAM) bertujuan untuk menjelaskan dan memperkirakan penerimaan (acceptance) pengguna terhadap suatu sistem informasi. TAM menyediakan suatu basis teoritis untuk mengetahui faktor-faktor yang mempengaruhi penerimaan terhadap suatu teknologi dalam suatu organisasi. TAM menjelaskan hubungan sebab akibat antara keyakinan (akan manfaat suatu sistem informasi dan kemudahan penggunaannya) dan perilaku, tujuan/keperluan, dan penggunaan aktual dari pengguna/user suatu sistem informasi.

\section{E-commerce}

Baum (1999) dalam Purbo dan Wahyudi (2001) memberi definisi e-commerce merupakan satu set dinamis teknologi, aplikasi, dan proses bisnis yang menghubungkan perusahaan, konsumen, dan komunitas tertentu melalui transaksi elektronik dan perdagangan barang, pelayanan, dan informasi yang dilakukan secara elektronik. E-commerce atau perdagangan elektronik adalah pembelian dan penjualan barang atau jasa melalui sistem elektronik seperti internet dan jaringan komputer lainnya (Hall, 2007).

\section{Sistem Informasi Akuntansi}

Sistem Informasi Akuntansi (SIA) adalah serangkaian prosedur formal di mana data dikumpulkan, diproses menjadi informasi dan didistribusikan ke para pengguna (Hall, 2007). Dalam sistem informasi akuntansi terjadi rangkaian proses seperti mengidentifikasi, mengumpulkan, memproses, dan mengkomunikasikan informasi ekonomi tentang sebuah perusahaan menggunakan berbagai teknologi. SIA juga menangkap dan mencatat dampak keuangan dari transaksi yang terjadi di perusahaan serta mendistribusikan informasi transaksi ke personel operasi untuk mengkoordinasikan berbagai tugas utamanya (Hall, 2007).

\section{Pengembangan Hipotesis}

Technology Acceptance Models (TAM) yang dirumuskan Davis et al. (1989) menunjukkan bahwa kemudahan penggunaan yang dirasakan berpengaruh terhadap manfaat yang dirasakan. Davis (1989) mendefinisikan kemudahan penggunaan yang dirasakan sebagai suatu tingkatan dimana seseorang percaya bahwa penggunaan sistem tertentu dapat mengurangi usaha seseorang dalam mengerjakan sesuatu.

Agarwal dan Prasad (1999) menyatakan bahwa ada hubungan yang positif antara kemudahan penggunaan yang dirasakan dengan manfaat yang dirasakan. Manfaat yang dirasakan didefinisikan sebagai tingkat keyakinan individu bahwa dalam menggunakan sistem atau teknologi tertentu akan meningkatkan kualitas kerjanya (Davis, 1989; Davis et al. 1989). 
Penelitian Lesmono (2015), Lestari, et al. (2014) serta Putri (2010) dan Suprapti (2016) menunjukkan hasil yang signifikan mengenai pengaruh kemudahan penggunaan yang dirasakan dalam penggunaan teknologi baik secara langsung maupun tidak langsung pada manfaat yang dirasakan. Oleh karena itu, diajukan hipotesis berikut:

H1: Kemudahan Penggunaan yang Dirasakan (Perceived Ease Of Use) Berpengaruh Positif Terhadap Manfaat yang Dirasakan (Perceived Usefulness) Dalam Menggunakan ECommerce pada UMKM Di Kota Bengkulu.

Technology Acceptance Models (TAM) yang dirumuskan Davis (1989) menunjukkan bahwa kemudahan penggunaan yang dirasakan berpengaruh terhadap sikap terhadap penggunaan. Davis (1989) mendefinisikan kemudahan penggunaan yang dirasakan sebagai suatu tingkatan dimana seseorang percaya bahwa penggunaan sistem tertentu dapat mengurangi usaha seseorang dalam mengerjakan sesuatu.

Penelitian Lestari, et al. (2014), Lesmono (2015), dan Putri dan Suprapti (2016) menunjukkan hasil yang signifikan mengenai pengaruh kemudahan penggunaan yang dirasakan terhadap sikap terhadap penggunaan. Oleh karena itu, diajukan hipotesis berikut:

H2: Kemudahan Penggunaan yang Dirasakan (Perceived Ease Of Use) Berpengaruh Positif Terhadap Sikap Terhadap Penggunaan (AttitudeTowards Using) Dalam Menggunakan E-

Commerce pada UMKM Di Kota Bengkulu.

Technology Acceptance Models (TAM) yang dirumuskan Davis et al.(1989) menunjukkan bahwa manfaat yang dirasakan berpengaruh terhadap sikap terhadap penggunaan. Manfaat yang dirasakan didefinisikan sebagai tingkat keyakinan individu bahwa dalam menggunakan sistem atau teknologi tertentu akan meningkatkan kualitas kerjanya (Davis, 1989). Jika manfaat yang dirasakan meningkat maka sikap terhadap penggunaan akan meningkat pula. Barret et al. (1986), serta Schultz dan Slevin (1975) menyatakan adanya hubungan positif yang konsisten antara manfaat yang dirasakandan sikap terhadap penggunan.

Penelitian Poetri (2010), Lesmono (2015), dan Putri dan Suprapti (2016) menunjukkan hasil yang signifikan mengenai pengaruh manfaat yang dirasakan terhadap sikap penggunaan. Oleh karena itu, diajukan hipotesis berikut:

H3: Manfaat yang Dirasakan (Perceived Usefulness) Berpengaruh Positif Terhadap Sikap Terhadap Penggunaan (Attitude Towards Using) Dalam Menggunakan E-Commerce pada UMKM Di Kota Bengkulu.

Menurut Technology Acceptance Moels (TAM), niat untuk menggunakan selalu dipengaruhi secara langsung oleh manfaat yang dirasakan (Davis et al. 1989). Manfaat penggunaan yang dirasakan didefinisikan sebagai tingkat keyakinan individu bahwa dalam menggunakan sistem atau teknologi tertentu akan meningkatkan kualitas kerjanya (Davis, 1989).

Penelitian dalam sistem informasi community menyatakan bahwa terdapat hubungan yang positif antara manfaat yang dirasakan dengan niat menggunakan (Agarwal dan Prasad, 1999).

Penelitian Poetri (2010), Supriono (2015), dan Putri dan Suprapti (2016) menunjukkan hasil yang signifikan mengenai pengaruh manfaat yang dirasakan terhadap niat untuk menggunakan. Oleh karena itu, diajukan hipotesis berikut:

H4: Manfaat Penggunaan yang Dirasakan (Perceived Usefulness) Berpengaruh Positif

Terhadap Niat Untuk Menggunakan (Intention To Use) E-Commerce pada UMKM Di

Kota Bengkulu.

Technology Acceptance Models (TAM) yang dirumuskan Davis et al. (1989) menunjukkan bahwa sikap terhadap penggunaan berpengaruh terhadap niat untuk menggunakan. 
Hubungan antara sikap terhadap penggunaan dan niat untuk menggunakan merupakan dasar dari TRA. Triandis (1977) dan Bagozzi (1981) menyatakan ada hubungan positif antara sikap terhadap penggunaan dan niat untuk menggunakan.

Penelitian Poetri (2010), Lestari, et al. (2014), Supriono (2015), Lesmono (2015), dan Putri dan Suprapti (2016) menunjukkan hasil yang signifikan mengenai pengaruh sikap terhadap penggunaan terhadap niat untuk menggunakan. Oleh karena itu, diajukan hipotesis berikut:

H5: Sikap Terhadap Penggunaan (Attitude Towards Using) Berpengaruh Positif Terhadap Niat Untuk Menggunakan (Intention To Use) E-Commerce pada UMKM Di Kota Bengkulu.

Gambar 1. Kerangka Penelitian

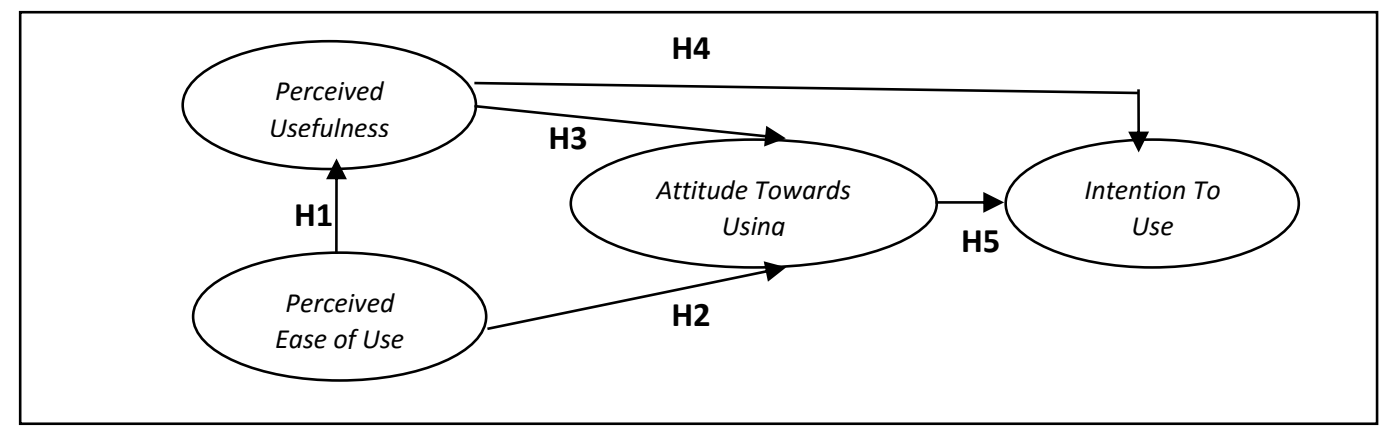

Sumber: dikembangkan untuk penelitian ini (2017)

\section{METODE PENELITIAN}

\section{Metode Pengambilan Sampel}

Sampel adalah bagian dari sejumlah karakteristik yang dimiliki populasi yang digunakan untuk penelitian (Sujarweni, 2014). Sampel dalam penelitian ini dijadikan sebagai objek pengamatan dalam penelitian ini adalah pelaku UMKM Di Kota Bengkulu. Jumlah sampel dalam penelitian ini ditentukan sebanyak 100 sampel, yang dirasa sudah cukup untuk mewakili populasi.

Selanjutnya dari sejumlah sampel minimal tersebut, dari setiap responden akan dipilih lagi mana responden yang dapat digunkan kuesionernya dengan teknik purposive sampling. Purposive sampling adalah teknik penentuan sampel dengan pertimbangan tertentu (Sugiyono, 2012). Kriteria responden yang ditentukan untuk penelitian ini adalah:

1. Merupakan pelaku UMKM (Usaha Mikro, Kecil dan Menengah) dan terdaftar pada sektor perdagangan di Dinas Koperasi dan UMKM Kota Bengkulu.

2. Belum pernah menggunakan e-commerce namun telah mengenal e-commerce.

3. Sudah pernah mengikuti pelatihan dan pengembangan teknik akuntansi penjualan online, pencatatan serta pembukuan transaksi perdagangan melalui media online dan pelatihan sejenisnya yang diadakan oleh Dinas Koperasi dan UMKM di Kota Bengkulu.

\section{Pengukuran dan Definis Operasional Variabel}

Manfaat yang dirasakan didefinisikan sebagai tingkat keyakinan individu bahwa dalam menggunakan sistem atau teknologi tertentu akan meningkatkan kualitas kerjanya (Davis, 1989). Dalam penelitian ini yang dimaksud manfaat penggunaan yang dirasakan adalah tingkat keyakinan pelaku Usaha Mikro, Kecil dan Menengah (UMKM) bahwa dalam menggunakan $e$ commerce akan meningkatkan kualitas usahanya melalui kemudahan sistem akuntansi penjualan dan penerimaan kas. 
NIAT MENGGUNAKAN E-COMMERCE...

Fatrisya Marsyadini dan Nila Aprila

Variabel ini diukur menggunakan kuesioner yang terdiri dari enam item pernyataan yang diadopsi dari penelitian Davis (1989) dan penelitian Poetri (2010) yang disesuaikan lagi oleh peneliti. Kuesioner ini menggunakan skala likert 5 poin. Skala ini terdiri dari angka 1 yang menunjukkan sangat tidak setuju, angka 2 tidak setuju, angka 3 netral, angka 4 setuju dan angka 5 sangat setuju.

\section{Metode Analisis Data}

\section{Statistik Deskriptif}

Statistik deskriptif digunakan untuk menganalisis dan menyajikan sebagian besar data. Statistik deskriptif menampilkan nilai rata-rata (mean), ukuran penyebaran (standar deviasi), dan bentuk distribusi (nilai minimum dan maksimum) data (Cooper dan Schindler, 2012).

\section{Teknik Analisis Data}

Analisis data dalam penelitian ini menggunakan pendekatan Partial Least Square (PLS). Hal ini dikarenakan penelitian ini adalah penelitian kuantitatif dengan tiga variabel laten endogen (dependen) dan satu variabel laten eksogen (independen), menurut Abdillah dan Jogiyanto (2015) PLS baik digunakan pada penelitian kuantitatif yang menggunakan model penelitian yang kompleks, yaitu model yang terdiri atas banyak variabel dependen dan variabel independen (model kompleks) dan yang menggunakan efek mediasi atau moderasi.

\section{Outer Model}

Outer Model (Model Pengukuran) digunakan untuk mengetahui validitas dan reliabilitas yang menghubungkan indikator dengan konstruk atau variabel latennya.

\section{Uji Kualitas Data}

Uji validitas dilakukan untuk menunjukkan seberapa nyata suatu pengujian mengukur apa yang seharusnya diukur (Cooper dan Schindler, 2012).

Reliabilitas adalah suatu tingkatan yang mengukur konsistensi hasil jika dilakukan pengukuran berulang pada suatu karakteristik (Malhotra dan Birks, 2007). Reliabilitas konstruk dalam penelitian ini akan diukur dengan menggunakan composite reliability. Untuk dapat dikatakan suatu konstruk reliabel, maka nilai composite reliability harus lebih besar dari 0,7 (Abdillah dan Jogiyanto, 2015).

\section{Inner Model}

Menurut Ghozali (2014) Pengujian inner model atau model struktural dilakukan untuk melihat hubungan antara konstruk, nilai signifikansi dan $R$-square.

\section{Model Persamaan Penelitian}

Penelitian ini menggunakan analisis jalur. Persamaan yang digunakan dalam penelitian ini adalah rancangan uji hipotesis dalam penelitian ini disajikan berdasarkan tujuan penelitian. Tingkat kepercayaan yang digunakan adalah 95\%, sehingga tingkat presisi sebesar $(\alpha)=5 \%=$ 0,05, dan menghasilkan nilai t-tabel sebesar 1,663. 


\section{HASIL PENELITIAN DAN PEMBAHASAN}

\section{Statistik Deskriptif}

Statistik deskriptif data penelitian ini dapat kita lihat dari nilai rata-rata (mean), nilai minimum dan maksimum serta nilai standar deviasi. Data ini digunakan untuk memberikan gambaran tentang tanggapan responden. Mean merupakan hasil penjumlahan nilai seluruh data dibagi dengan banyak data. Standar deviasi adalah akar dari jumlah kuadrat dari selisih nilai data dengan rata-rata dibagi dengan banyaknya data.

\section{Evaluasi Outer Model}

Penelitian ini menggunakan persamaan model struktural yang dianalisis menggunakan program SmartPLS 2.0 M3. Model pengukuran (outer model) ini digunakan untuk mengetahui validitas dan reabilitasnya yang menghubungkan indikator dengan variabel latennya. Evaluasi ini dilakukan dengan menggunakan PLS Algorithm.

\section{Validitas Konvergen}

Suatu indikator dinyatakan valid jika mempunyai loading factor diatas 0,7 terhadap konstruk yang dituju. Adapun output SmartPLS untuk loading factor memberikan hasil pada Gambar :

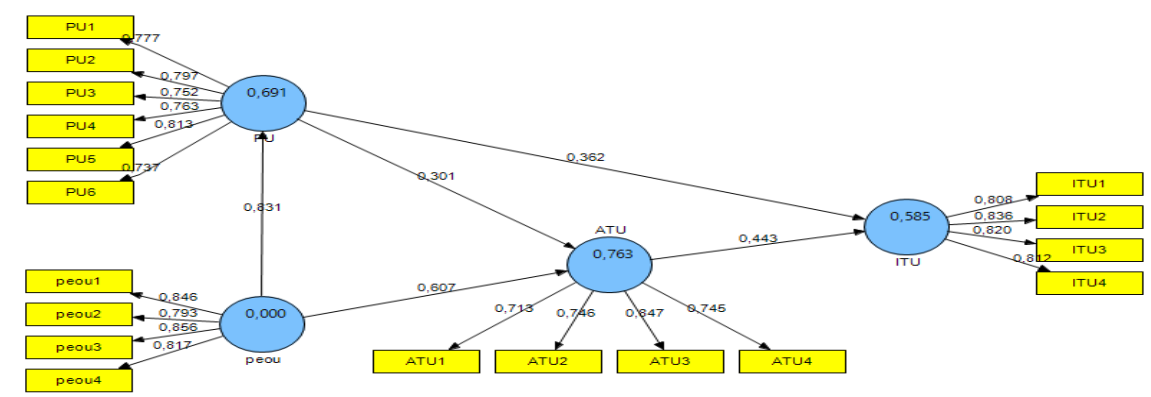

Gambar 2. Hasil PLS Algorithmsecara Full

\section{Uji Reliabilitas}

Selain menggunakan uji validitas untuk konstruk, perlu juga dilakukan pengujian reliabilitas yang diukur dengan menggunakan composite reliability dan diperkuat dengan nilai Cronbach's alpha dari blok indikator yang mengukur konstruk. Hasil composite reliability akan menunjukkan nilai yang memuaskan jika berada di atas 0,7 dan Cronbach's alpha nya di atas 0,60. Nilai composite reliability dan cronbach'salpha ditunjukkan pada Tabel.

\section{Tabel 4.7}

Composite Reliability dan Cronbach's Alpha

\begin{tabular}{l|l|l}
\hline & Composite Reliability & Cronbach's Alpha \\
\hline ATU & 0,848524 & 0,761455 \\
\hline ITU & 0,890780 & 0,837199 \\
\hline PU & Composite Reliability & Cronbach's Alpha \\
\hline PEOU & 0,899214 & 0,865461 \\
\hline
\end{tabular}

Sumber : Data Primer telah diolah, 2017 
NIAT MENGGUNAKAN E-COMMERCE...

Fatrisya Marsyadini dan Nila Aprila

\section{Evaluasi Inner Model}

Setelah menggunakan model yang diestimasi memenuhi kriteria Outer Model, berikutnya adalah melakukan pengujian model struktural (inner model) menggunakan $R$-Square model untuk konstruk dependen (endogen) dan uji t seta signifikan dari koefisien parameter struktural. Adapun model struktural hasil PLS Boothstrapping dalam penelitian ini terlihat pada Gambar

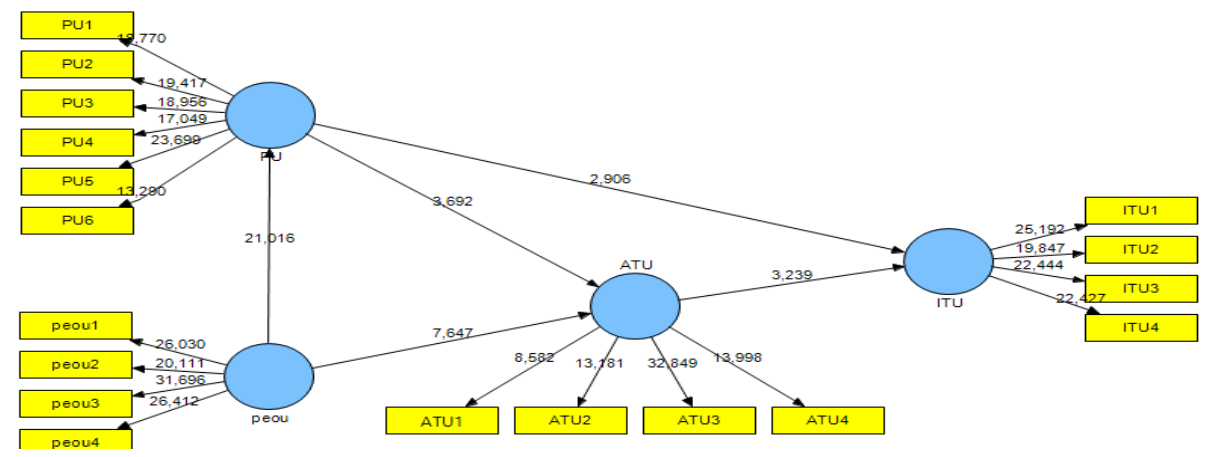

Data Primer telah diolah, 2017

Gambar 3. Tampilan Boothstrapping

\section{Pengujian Hipotesis}

Hipotesis penelitian dapat diuji menggunakan metode boothstrapping dengan melihat signifikan model dalam pengujian model struktural dapat dilihat dari nilai t statistik dalam Tabel :

\begin{tabular}{l|l|l}
\hline No & Hipotesis & Hasil \\
\hline $\mathbf{1}$ & $\begin{array}{l}\text { Kemudahan penggunaan yang dirasakan (perceived ease of use) berpengaruh positif terhadap manfaat } \\
\text { yang dirasakan (perceived usefulness) dalam menggunakan } \text {-commerce pada UMKM di Kota Bengkulu }\end{array}$ & Diterima \\
\hline $\mathbf{2}$ & $\begin{array}{l}\text { Kemudahan penggunaan yang dirasakan (perceived ease of use) berpengaruh positif terhadap sikap } \\
\text { dalam penggunaan (attitude towards using) dalam menggunakan e-commerce pada UMKM di Kota } \\
\text { Bengkulu }\end{array}$ & Diterima \\
\hline $\mathbf{3}$ & $\begin{array}{l}\text { Manfaat yang dirasakan (perceived usefulness) berpengaruh positif terhadap sikap terhadap penggunaan } \\
\text { (attitude towards using) dalam menggunakan } \text { e-commerce pada UMKM di Kota Bengkulu }\end{array}$ & Diterima \\
\hline $\mathbf{4}$ & $\begin{array}{l}\text { Manfaat penggunaan yang dirasakan (perceived usefulness) berpengaruh positif terhadap niat untuk } \\
\text { menggunakan (intention to use) dalam menggunakan } e \text {-commerce pada UMKM di Kota Bengkulu }\end{array}$ & Diterima \\
\hline $\mathbf{5}$ & $\begin{array}{l}\text { Sikap terhadap penggunaan (attitude towards using) berpengaruh positif terhadap niat untuk } \\
\text { menggunakan (intention to use) dalam menggunakan } e \text {-commerce pada UMKM di Kota Bengkulu }\end{array}$ & Diterima \\
\hline
\end{tabular}

Tabel menunjukkan bahwa hubungan antara PEOU dengan PU adalah signifikan dengan T-statistik sebesar 21,016241 (>1,663). Nilai original sample estimate adalah positif yaitu sebesar 0,831119 yang menunjukkan bahwa arah pengaruh antara PEOU dengan PU adalah positif. Dengan demikian hipotesis $\mathrm{H} 1$ dalam penelitian ini diterima.

Tabel menunjukkan bahwa pengaruh antara PEOU dengan ATU adalah signifikan dengan T-statistik sebesar 7,647274 (>1,663). Nilai original sample estimate adalah positif yaitu sebesar 0,607395 yang menunjukkan bahwa arah pengaruh antara PEOU dengan ATU adalah positif. Dengan demikian hipotesis $\mathrm{H} 2$ dalam penelitian ini diterima.

Tabel 4.9 menunjukkan bahwa pengaruh antara PU dengan ATU adalah signifikan dengan T-statistik sebesar 3,691992 (>1,663). Nilai original sample estimate adalah positif yaitu sebesar 0,301036 yang menunjukkan bahwa arah pengaruh antara PU dengan ATU adalah positif. Dengan demikian hipotesis H3 dalam penelitian ini diterima. 
Tabel 4.9 menunjukkan bahwa pengaruh antara PU dengan ITU adalah signifikan dengan T-statistik sebesar 2,905930 (>1,663). Nilai original sample estimate adalah positif yaitu sebesar 0,361597 yang menunjukkan bahwa arah pengaruh antara PU dengan ITU adalah positif. Dengan demikian hipotesis H4 dalam penelitian ini diterima.

Pada tabel 4.9 menunjukkan bahwa pengaruh antara ATUdengan ITU adalah signifikan dengan T-statistik sebesar 3,239228 (>1,663). Nilai original sample estimate adalah positif yaitu sebesar 0,442818 yang menunjukkan bahwa arah pengaruh antara ATU dengan ITU adalah positif. Dengan demikian hipotesis H5 diterima.

\section{PENUTUP}

\section{Simpulan}

Penelitian ini dilakukan untuk membuktikan pengaruh manfaat yang dirasakan (perceived usefulness), kemudahan dalam penggunaan yang dirasakan (perceived ease of use), sikap terhadap penggunaan (attitude toward using), niat untuk menggunakan (intention to use) e-commerce terhadap usaha bisnis UMKM di kota Bengkulu.

Berdasarkan pada hasil penelitian yang telah peneliti lakukan maka dapat disimpulkan beberapa hal yaitu

1. Kemudahan penggunaan yang dirasakan (perceived ease of use) berpengaruh positif terhadap manfaat yang dirasakan (perceived usefulness) dalam menggunakan e-commerce pada UMKM di Kota Bengkulu.

2. Manfaat yang dirasakan (perceived usefulness) berpengaruh positif terhadap sikap terhadap penggunaan (attitude towards using) dalam menggunakan e-commerce pada UMKM di Kota Bengkulu.

3. Kemudahan penggunaan e-commerce yang dirasakan (perceived ease of use) berpengaruh positif terhadap sikap terhadap penggunaan (attitude towards using) dalam menggunakan e-commerce pada UMKM di Kota Bengkulu.

4. Sikap terhadap penggunaan (attitude towards using) berpengaruh positif terhadap niat untuk menggunakan (intention to use) dalam menggunakan e-commerce pada UMKM di Kota Bengkulu.

5. Manfaat yang dirasakan (perceived usefulness) berpengaruh positif terhadap terhadap niat untuk menggunakan (intention to use) dalam menggunakan e-commerce pada UMKM di Kota Bengkulu.

\section{Saran}

Berdasarkan hasil penelitian, pembahasan dan kesimpulan di atas serta pertimbangan masih adanya keterbatasan dalam penelitian ini, maka untuk penelitian selanjutnya dapat mempertimbangkan saran-saran yaitu

1. Sebaiknya data yang digunakan merupakan usaha kecil menengah yang sebenarnya dengan mengikuti kriteria di undang-undag tentang UMKM, yang terdaftar di Dinas Koperasi.

2. Sebaiknya pernyataan-pernyataan yang digunakan di kuesioner diadopsi dari kuesioner yang mudah dipahami dan secara umum bisa dimengerti oleh siapapun.

\section{Keterbatasan Penelitian}

Beberapa keterbatasan yang ada dalam penelitian ini adalah sebagai berikut :

1. Peneliti mengumpulkan data UMKM berdasarkan data dari Dinas Koperasi dan UMKM Di Kota Bengkulu. Data tersebut menunjukkan bahwa semua jenis usaha merupakan 
Fatrisya Marsyadini dan Nila Aprila

bagian dari UMKM, tidak ada pemisah antara Usaha Mikro maupun Usaha Kecil Menengah. Sehingga peneliti memilih responden hanya dengan melihat omset/aset yang besar dari rata-rata keseluruhan usaha.

2. Keterbatasan yang melekat pada data yang diperoleh melalui alat kuesioner, adanya kemungkinan bias yang disebabkan oleh perbedaan persepsi antara peneliti dan responden terhadap pernyataan-pernyataan yang diajukan.

\section{DAFTAR PUSTAKA}

Aaker, David, A dan Myers, John, G. 1997. Advertising Management. New Jersey: Prentce Hall inc.

Abdillah, Willy dan Jogiyanto. 2015. Partial Least Square (PLS) - Alternatif Structural Equation Modeling (SEM) dalam Penelitian Bisnis. Yogyakarta: CV. Andi Offset.

Agarwal, R. and Prasad, J. 1999."Are Individual Differences Germane To The Acceptance Of New Information Technologies?", Decision Sciences, Vol.30 No.2,pp.361-91

Ajzen, I. \& Fishbein, M. 1975. Belief, Attitude, Intention, and Behavior: An Introduction to Theory and Research, 129-385, Addison-Wesley, Reading, MA.

Ajzen. I. 1991. The Theory of Planned Behaviour. Organizational Behaviourand Human Decision Process. Amherst, MA: Elsevier.

Ajzen, Icek. 1988. from intentions to actions: attitudes, personality, \& behavior. Chicago: Dorsey Press.

Ajzen, I. and Fishbein, M. 1980. Understanding Attitudes and Predicting Social Behavior. Englewood Cliffs, New Jersey: Prentice Hall.

Bagozzi, R. P. 1981. "Attitudes, Intention and Beavior; A test of some key hypothesis", Journal of Personality and Social Psychological, 41, $607-626$

Barret, G.V., Thornton, C. L., \& Cabe, P.A. 1968, Human Factors Evaluation of A Computer Bassed Information System and Retrieval System. Human Factors, 10, 431-436

Bodnar, George H, and William S. Hopwood. 2006. Sistem Informasi Akuntansi, Buku I. Jakarta: Penerbit salemba empat.

Chau, P. Y. K. 1996. An Emperical Investigation on Factors Affecting The Acceptance of CASE by Systems Developers. Information \& Management, 30, 269-280.

Chin, W. W. 1998. The Partial Least Squares Approach to Structural Equation Modeling. In G. A. Marcoulides (Ed.). Modern Methods for Business Research (295-336). Mahwah, New Jersey, London: Lawrence Eribaum Associates.

Cooper, Donald R. \& Schindler, Pamela S. 2012. Business Research Methods, 12th ed. New York: McGraw-Hill.

Davis, F. D. 1989. Perceived Usefulness, Perceived Ease of Use, and User Acceptance of Information Technology. MIS Quarterly, 13(3), 319-340.

Davis, F. D., R. P. Bagozzi \& PR. Washaw. 1989. User Acceptance of Computer Technology: A Comparison of Two Theoritical Models. International Journal Management Machine Studies, August, 35(8), 982-1003.

Ferdinand, Augusty. 2006. Metode Penelitian Manajemen: Pedoman Penelitian untuk SPenulisan Skripsi, Tesis dan Disertasi Ilmu Manajemen. Semarang: Badan Penerbit Universitas Diponegoro,

Fornell, C. \& Larcker, D.F. 1981. Evaluating Structural Equation Models with Unobservable Variables and Measurement Error. Journal of Marketing Research. 18 (1), 39-50.

Ghozali, Imam. 2014.Structural Equation Modeling Metode Alternatif dengan Partial Least Square. Edisi 4. Semarang: Badan Penerbit Universitas Diponegoro.

Hall, James A. 2007. Sistem Informasi Akuntansi. Edisi Ketiga Terjemahan Amir Abadi Yusuf. Jakarta: Salemba Empat. 
Igbaria, M., Guimaraes, T. \& Davis, G.B. 1997. Testing the Determinants of Microcomputer Usage via a Structural Equation Model. Journal of Management Information Systems, (11), 87-114.

Indriantoro dan Supomo, 2002. Metodologi Penelitian Bisnis untuk Akuntansi dan Manajemen, Edisi Pertama, BPFE-Yogyakarta, Yogyakarta.

Intan, Raden Ajeng dan Warsono, Sony. 2014. Pengaruh Faktor-Faktor Internal Dan Eksternal Terhadap Penggunaan E-Commerce Pada Usaha Kecil Menengah (UKM). Tesis tidak diterbitkan. Jurusan Ilmu Akuntansi/Akuntansi Terapan Universitas Gadjah Mada, Yogyakarta.

Jogiyanto, H. M. 2007. Sistem Informasi Keperilakuan. Edisi Revisi. Yogyakarta: Andi.

Jogiyanto. H. M. 2005. Analisis dan Desain Sistem Informasi. Yogyakarta: Andi

Lesmono, Ibnu Dwi. 2015. Pengaruh Penggunaan E-Commerce Bagi Pengembangan Usaha Kecil Menengah (UKM) Dengan Pendekatan Technology Acceptance Model. Jurnal Evolusi, 3 (1), 49-60.

Lestari, Yuni Puji, Setyowati, Nuning, dan Ihsaniyati, Hanifah. 2014. Dampak Pengaruh Sosial dan Kondisi Fasilitas Terhadap Niat Adopsi Media Sosial oleh UMKM Rotan di Kecamatan Gatak Kabupaten Sukoharjo. E-Journal AGRISTA. 3 (2), 1-14.

Malhotra, N. K. and Birks, D.F. 2007. Marketing Research: An Apllied Approach. 3rd European Edition. Harlow, UK: Pearson Education.

Maskur, Abdullah. 2005 .Lilitan Masalah Usaha Mikro, Kecil, Menegah (UMKM) \&. Kontroversi Kebijakan. Medan: Bitra Indonesia.

Mulyadi, 2001. Sistem Akuntansi. Edisi Ketiga. Cetakan Ketiga. Jakarta: Salemba Empat.

Nicolaou, A. I. 2000. A contingency model of perceived effectiveness in accounting information systems: Organizational coordination and control. International Journal of Accounting Information Systems, 1, 2, pp. 91-105.

Purbo, O. W. \& Wahyudi, A. A. 2001. Mengenal E-Commerce. Jakarta: Elex Media Komputindo.

Poetri, Adellia Rosarindry. 2010. Adopsi E-Commerce Dengan Pendekatan Technology Acceptance Model (TAM) Bagi UKM. Skripsi. Ekonomi, Manajemen, Universitas Sebelas Maret Surakarta.

Putri, Ni Made Kania I, dan Suprapti, Ni Wayan Sri. 2016. Aplikasi Model TAM dalam Menjelaskan NiatMenggunakan Mobile Commerce di Kota Denpasar. E-Jurnal Manajemen Unud, 5 (4), 2341-2368.

Sarwono, Jonathan. 2006. Metode Penelitian Kuantitatif dan Kualitatif. Yogyakarta: Graha Ilmu.

Sarwono, Jonathan. 2007. Analisis Jalur Untuk Riset Bisnis: Aplikasi Riset Pemasaran, Keuangan, MSDM dan Kewirausahaan. Yogyakarta: Penerbit Andi.

Schultz dan Slevin. 1975. "Implementation and Organizational Validity: An empirical Investigation". Implementating OperationResearch Management Science. New York.

Sekaran, Uma. 2006. Metodologi Penelitian untuk Bisnis Buku 1 dan 2 Edisi Pertama. Jakarta: Salemba Empat.

Sugiyono. 2012. Metode Penelitian Administrasi. Cetakan Ke-20. Bandung: Alfabeta.

Sugiyono. 2009. Metode Penelitian Kuantitatif, Kualitatif dan R\&D. Bandung: Alfabeta.

Sujarweni, V. Wiratna. 2014. Metodologi Penelitian. Yogyakarta: Pustaka Baru Press.

Supriono. 2015. Pengaruh Sikap, Norma Subyektif, Persepsi Penggunaan dan Persepsi Kemudahan Penggunaan Terhadap Penggunaan Sistem Informasi Akuntansi dengan Minat Penggunaan sebagai Variabel Moderasi. Jurnal Ekonomi dan Teknik Informatika, 3 (2), 1-15.

Taylor, S. and P.A. Todd. 1995. "Understanding Information Technology Usage: A Test of Competing Models." Information Systems Research, 6 (2), 144-176. 
NIAT MENGGUNAKAN E-COMMERCE...

Fatrisya Marsyadini dan Nila Aprila

Triandis, H. C. 1977. Interpersonal Behavior. Monterey, Calif.: Brooks/Cole Pub. Co.

Undang-Undang Republik Indonesia Nomor 20 Tahun 2008 Tentang Usaha Mikro, Kecil, dan Menengah.

Utami, Sri Setyaningsih. 2010. Pengaruh Teknologi Informasi Dalam Perkembangan Bisnis. Jurnal Akuntansi dan Sistem Teknologi Informasi, 8 (1), 61-67.

Yuliana, Oviliani Y. 2000. Penggunaan Teknologi Internet dalam Bisnis. Jurnal Akuntansi dan Keuangan. Vol. 2, No. 1, Mei 2000: 36-52. 